\title{
THE LEARNINGS OF THE BASIC EDUCATION TEACHER
}

\author{
Joana Paulin Romanowski \\ Programa de Pós-Graduação, Centro Universitário Uninter (Brazil)
}

\begin{abstract}
The research has as object of study the learning of basic education teachers in order to identify the learning of basic education teachers in their professional performance that contribute to their teacher education. The survey was conducted through a questionnaire using the Lickert scale answered on the google forms platform. 370 teachers from all regions of Brazil participated in the research. The study references are based Zeichner (2008), Martins (2009, 2016). In the analysis of the answers, the highest index of the scale was considered for the indication of the percentages. None of the answers obtained a $100 \%$ indication of the highest index on the scale. The responses with the highest number of responses were grouped into the following categories: teachers learn in (i) collective teaching practice and management in the school space; (ii) in their own teaching practice; (iii) with the reflection of its practice; (iv) in courses, lectures and (v) by conducting individual studies. The responses with the lowest index refer to learning: in informal spaces, on the internet and with the parents of their students. The most valued responses refer to learning: sharing problems; of ideas and opinions about education; planning classes in collaboration with school teachers; teaching together with another teacher in the same class; insertion of new teaching methods and innovations; they participate in school coordination councils where new possibilities are discussed and in many situations they read, consult; they prepare and develop workshops at the school to support teachers at the school and other schools. Teachers emphasize as a strong possibility of reflection and investigation their practice in the act of teaching and learning by reviewing the experiences: contradictions between the ideas about teaching and how they are put into teaching practice; when the teacher describes his practice to other people. By examining his experiences in practice, observing the strengths and weaknesses, and in reflections on his own beliefs and conceptions about teaching, the teacher has the opportunity to change his practice. The conclusions indicate that the teacher's practice contributes to his education.
\end{abstract}

Keywords: Teaching practice, teaching, basic education, teacher education.

\section{Introduction}

This article presents a research carried out by the Education, Technology and Society Research Group, of the Education and New Technologies Graduate Program at UNINTER and has as its object the study of the educational practice carried out in the school in the perspective of the informal formation of the teacher. The investigation assumes to understand the relations of the teaching action with the sociocultural interferences in the daily life of this practice and the implications with the teacher formation. The analysis process takes practice to, from there, understand the relationships that guide it. The resulting theory is an expression of this practice (Martins, 2009, 2016). $m$ the object of study is the formation of the teacher in informal interactions.

The study of the processes of training, learning and development of the teaching professional has been a constant in educational research. The concepts of "teacher learning", "professional teacher development", "teacher training" or even "teacher change" have generated lines of research whose results are shown in different manuals published by the AERA (American Educational Research Association) and by prestigious publishers.

\section{Objectives}

The research aims to answer the question: How do teachers learn in a society that connects? More specifically, we aim to: learn how the learning processes are carried out by 21 st century teachers, in a connected society that offers alternative non-formal and informal ways to improve teachers' professional knowledge. To answer these objectives, the methodology collected qualitative data obtained through a questionnaire answered by teachers. 


\section{Methods}

For data collection, the questionnaire was made available on Google Forms and teachers from kindergarten, elementary and high school from cities in different regions of Brazil were invited. The questionnaire contains questions related to the identification of participants and questions about teaching learning. All questionnaire data were grouped and categorized. The distribution of participants by city, from the largest to the smallest, expresses the involvement of participants from capitals, medium-sized cities and cities in the interior. Curitiba is the city with the largest number of participants: 374 participants from the regions answered the questionnaire: Midwest 24; northeast 46; north 9; southeast 66; south 225. Regarding the degree of course of the participants, the data express that 4 teachers are graduated in medium level without graduation and the remaining 370 with graduation in licentiate courses. As for the type of institutions in which teachers are linked, there is a smaller number in private non-profit institutions.

\section{Discussion: Teachers' learning of teaching}

In carrying out this research, the concepts of "teacher learning", "professional teacher development", "teacher training" and "changing teaching practice" are considered. Among the authors who discuss the issue are considered: Gatti et all (2009), Martins (2016), Romanowski, Prates and Martins (2020); Romanowski, Saheb and Martins (2020); Romanowski, Cartaxo and Martins (2018), in addition to Gitomer and Bell, (2016); Loughran and Hamilton, (2016).

In the systematization and organization of responses, groupings were established considering the content of the questions answered, as follows: (i) learning in collective teaching practice and management in the school space; (ii) learning in their own teaching practice; (iii) learning from reflective practice; (iv) learning in other informal and collective spaces; (v) learning on the internet; (vi) teaching learning with interactions with parents; (vii) learning in courses, lectures; and (viii) learning by conducting individual studies.

Learning in collective teaching practices: The teachers participating in this research express that they learn intensively in the school space through the interactions of discussions about the practice in a collective way such as: sharing with fellow teachers the problems that arise in the school routine; when together with other teachers they try new teaching methods; at coordination council meetings at school; in the development of innovation projects in the school and when they prepare and develop workshops to exchange experiences. Hargreaves (2004) postulate that the school presents itself as a space for collective learning in a process of interaction of teachers' experiences.

Learning in your own teaching practice and reflection of its practice: In this grouping are numerous manifestations of learning by teachers in their own practice, as stated by Martins (2016, p. 36): teachers create alternatives to carry out their work practice. In this research, they were indicated as learning situations in their own practice, as the teachers point out, "I learn when" I adapt my way of teaching to the specificities of the content; I have my own experiences, with new teaching strategies; I analyze and try to understand why the wrong answers my students give to my questions; I reflect on my own beliefs and conceptions about teaching; I analyze the reactions of students in the class; and others.

Internet learning: Research and consultations on the internet assume an increasingly incisive incorporation and gained greater visibility during the pandemic caused by COVID 19, as pointed out by research by Romanowski et all (2020). Thus, teachers indicate learning in searches on the internet and social networks for content and resources for classes, with readings on education in journals, videos of teachers, consultation of websites, blogs, etc. teachers, with participation in courses and specializations in distance learning. During the pandemic due to the health crisis caused by Covid 19, internet learning intensified. In Brazil, this process of classes held remotely by applications with Zoom, Meet, Teams, in which teachers and students were present during the class, but distanced in space, was called remote classes.

Learning by conducting individual studies and courses: Conducting individual studies favors learning when reading educational journal articles, about the content of the taught material, in manuals in manuals and books on Education. Teachers indicate that they carry out individual research, favoring their professional development. The indication that they carry out studies is intense in their responses and there is evidence of the search for updating the knowledge on which teachers teach classes, such as reading: scientific articles, specialized books, psychopedagogy, on the stages of cognitive development and forms of human being learning, philosophy, where they seek to broaden their vision and understanding in several areas. 


\section{Conclusions}

It is noteworthy that the data collected favored the analyzes that, in comparison with the studied authors, can be highlighted:

(i) the collective process of developing intergroup research. This practice points out practice points out possibilities of favoring the exchange between researchers and areas of knowledge in the perspective of interdisciplinarity in order to expand scientific collaboration, deepening the discussion and analysis of the issues and problems investigated. This practice of conducting research in partnership favors a new academic culture, overcoming individualism and moving towards more collaborative practices as indicated in Martins (2016);

(ii) The contributions of informal training express an intensification of the valuation of teaching practice itself as a contribution to the process of teacher training. The realization of the action itself, without due reflection, confines itself to the act of carrying out the action, therefore, a contribution of teaching performance, in which training dispenses with reflection, as highlighted by Zeichner (2008). That is, it is by reflecting on the action that it is possible to understand this action.

(iii) The evidence expressed in the training provided by collective interactions, mainly in the school space, from meetings to conversations, as observed in Gohn (2008) and Trilla (2008). Teachers are increasingly making the transition from isolation, from individualization to the strengthening of teacher collectives by constituting communities, even though teachers continue to investigate and study to improve their professionalization.

(iv) Individual studies carried out based on the search for readings of the materials with which they work in the daily teaching and learning process. In the teachers' records, this effort that encourages the improvement of their training through these self-training initiatives is valued.

(v) Regarding the internet as a source of consultation for teachers. This informal consultation that contributes to the training process, both in consultations in repositories of articles and texts, as well as in social networks.

These notes favor understanding that the process of teacher training in the current context is expanded by the possibilities of formal training with an intensified offer in courses, lectures and events and that it enriches itself with the situations made possible by informal training.

Nowadays, with the increase of access to new sources of knowledge provided by digital media, by the valorization of collective training and informal and non-formal training, new perspectives of teacher professionalization are being guided.

We emphasize that this expansion by bringing contributions to teacher education, paradoxically, raises the demands for better professionalization of teachers, which is presented for research as issues to be investigated. The demands for improving teaching practice have been expanded, but working conditions remain precarious.

\section{References}

Gatti, B. A.; Barreto, E. S.; Andre, M. E. D. A. (2011). Políticas docentes no Brasil: um estado da arte. Brasília, DF: UNESCO.

Gitomer, D.; Bell, C. (Eds.) (2016). Handbook of Research on Teaching. New York: AERA.

Gohn, M. da G. (2011). Educação não-formal e cultura política. 5. ed. São Paulo: Cortez.

Hargreaves, A. (2004). O ensino na sociedade do conhecimento: a educação na era da insegurança. Porto Alegre: Artmed.

Loughran, J., Hamilton, M. L. (2016). International Handbook of Teacher Education. Singapore: Springer.

Martins, P.L. O. Pesquisa-ensino na formação inicial de professores e a interlocução com a educação Básica: princípios e metodologia. In: Romanowski, J. P.; Martins, P. L. O., Cartaxo, S. R. M. (Org.). Práticas de formação de professores: da Educação Básica à Educação Superior. (2016) Curitiba: Champagnat, v. 1, p. 01-20.

Martins, P.L. O. (2009). A didática e as contradições da prática. 3. ed. Campinas -SP: Papirus.

Romanowski, J. P.; Saheb, D.; Martins, P. L. O. (2020). Demandas para a formação dos professoresda educação básica no Brasil. Educatio- Revue scientifique. Education Chrétienne, v. 10.

Romanowski, J. P.; Prates, S. C.; Saheb, D.; Martins, P. L. O. Cartaxo, S. (2016). Práticas de formação de professores da Educação básica à Educação Superior. Curitiba: PUCPRess, p. 71-84

Romanowski, J. P.; Prates, S. C.; Martins, P. L. O. (2020). Aprendizagem da Docência para a educação básica em comunidades de prática. Revista Faeeba, v. 29, p. 61-77, 2020.

Trilla, J. A educação não-formal. In: Arante, V. A. (2008). Educação formal e não formal: pontos e contrapontos. São Paulo: Summus, 2008, 167p., p. 15-58.

Zeichner, K. M. (2008). Uma análise crítica sobre a "reflexão" como conceito estruturante na formação docente. Educ. Soc. [online]. 2008, vol.29, n.103, pp.535-554. 